\title{
Analysis of European policies and incentives for microgrids
}

\author{
J. F. Sanz ${ }^{1,2}$, G. Matute ${ }^{1}$, G. Fernández ${ }^{1}$, M. A. Alonso ${ }^{1}$, M. Sanz ${ }^{1,2}$ \\ ${ }^{1}$ Renewable Energy Integration Group \\ CIRCE Foundation, Zaragoza University \\ ${ }^{2}$ Electrical Engineering Department. University of Zaragoza \\ CIRCE Building, Campus Río Ebro, C/ Mariano Esquillor Gómez, 15 - Zaragoza, 50018 Zaragoza (Spain) \\ Phone number: +0034 976 761863, Fax number: +0034 976 732078, \\ e-mail: jfsanz@fcirce.es, gmatute@fcirce.es, gfa@unizar.es, malonso7@fcirce.es, msanz@fcirce.es
}

\begin{abstract}
One of the best solutions to face the problems in the current European electric systems is based on the implementation of microgrids as a way of increasing the consumption from renewable energy (RE) sources, improving energy efficiency, decreasing GHG emissions and, as a consequence, complying with European Commission (EC) 2020 targets. In this line, different EU regulations have been established but the particularities of each member state regulatory framework could appear as a barrier. For this reason, it is important to study how member states are carrying out the tasks associated with the penetration of microgrids, studying how European directives are transposed and incentives introduced. Besides, representative projects and demonstration cases for microgrids are shown, in order to determine the feasibility of the introduction of this novel concept in real situations.
\end{abstract}

\section{Key words}

Microgrid, policies, incentives, directives, renewable energies

\section{Introduction}

Currently, the EU electric system is based on centralized generation and consumption centres, which implies the following economic, environmental and technical disadvantages:

- Implementation of long and expensive transport and distribution lines supposing considerable energy losses [1].

- Power quality and security problems, especially in weak grids [2].

- Great variability in energy demand and difficult balance with generation.

As a solution, research projects have led to the microgrid concept as a system composed of a group of loads and microgeneration units operating as an only manageable system that supplies electric and/or thermal energy to a zone [3]. Other sources [4] consider the microgrid as the electric system composed of a coordinated group of generation and energy storage devices feeding several loads, in such a way that grid connected and islanded operation are possible. Fig. 1 illustrates this concept. Then, a microgrid presents several advantages in relation to the current electric model paving the way for a future definitive deployment:

- $\quad$ High power quality and guarantee of supply [5].

- Efficiency, mainly reducing losses in transport and distribution (over $8 \%$ according to [6]).

- Reduction of the dependence and demand from grid supply for consumers.

- Decrease of GHG emissions [7].

- Emergence of new ancillary markets and exploitation of excess of energy from distributed generation [8].

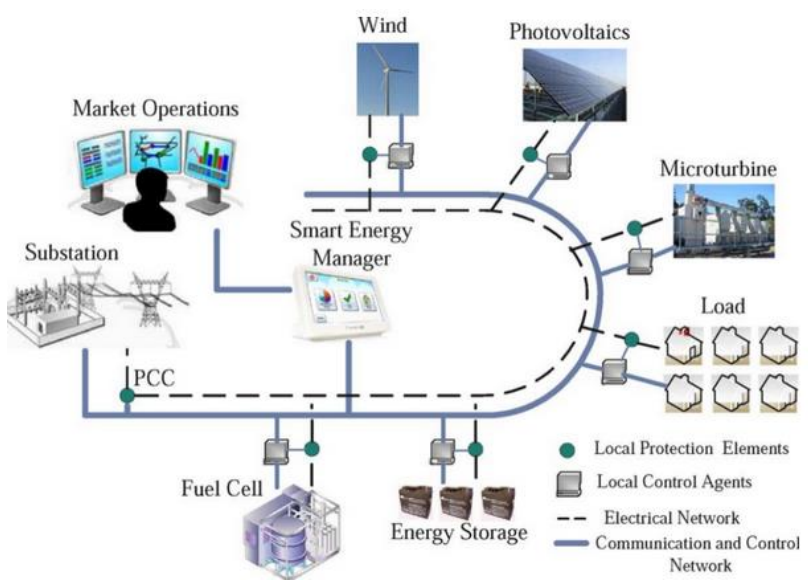

Fig. 1. Basic scheme of a microgrid [4]

In this way, the EC has launched different directives in line with the development of microgrids in the last decades and created the Smart Grids Task Force in 2009, proposing recommendations and standardization roadmaps in this field. 


\section{Microgrids: European energy policies and incentives}

\section{A. Policies and regulations}

Since there are not specific regulations for microgrids in the European Union, the fields gathered in Table 1 must be studied, in such a way that the main components of the microgrid are analysed. These regulations compose directives developed by the European Parliament and the Council. It is important to note that each member state transposes those directives following the particularities of its national regulatory framework. Nevertheless, these directives are a clear reference to study the general situation in Europe for microgrids. Table II presents the main directives for each field defined in Table I:

Table I. Regulatory fields for microgrids

\begin{tabular}{|l|l|}
\hline \multicolumn{1}{|c|}{ Directives objective } & Microgrid components considered \\
\hline Renewable Energies & Renewable generation units \\
\hline Grid connection & $\begin{array}{l}\text { Distribution grid connection } \\
\text { requirements for loads, } \\
\text { generation units and energy } \\
\text { storage devices }\end{array}$ \\
\hline $\begin{array}{l}\text { Self-consumption and } \\
\text { energy storage }\end{array}$ & $\begin{array}{l}\text { Conditions for delivering excess } \\
\text { of production, possibility of use } \\
\text { of storage systems... }\end{array}$ \\
\hline
\end{tabular}

Table II. European directives related to microgrids

\begin{tabular}{|c|c|}
\hline \multicolumn{2}{|r|}{ Renewable Energies } \\
\hline Directive & Contents \\
\hline 2009/28/EC & $\begin{array}{l}\text { The document sets renewable energy } \\
\text { targets: } 20 \% \text { share of renewable energy } \\
\text { sources and } 10 \% \text { of renewable energy in } \\
\text { transport sector by } 2020 \text {. National plans } \\
\text { must be established in line with these } \\
\text { goals. }\end{array}$ \\
\hline 2006/32/EC & $\begin{array}{l}\text { This directive aims to increase energy } \\
\text { efficiency in products and processes, } \\
\text { affecting to distribution system operators } \\
\text { and retailers. The main goal is to obtain } \\
\text { national final energy savings of } 9 \% \text { for } \\
\text { the } 9 \text { years of the validity period of the } \\
\text { directive. }\end{array}$ \\
\hline \multicolumn{2}{|r|}{ Grid Connection } \\
\hline Directive & Contents \\
\hline 2009/72/EC & $\begin{array}{l}\text { This directive sets the common regulatory } \\
\text { framework for generation, transport, } \\
\text { distribution and electrical supply, defining } \\
\text { the management and operation of the } \\
\text { electrical sector. }\end{array}$ \\
\hline \multicolumn{2}{|c|}{ Self-consumption and energy storage } \\
\hline Directive & Contents \\
\hline 2004/8/EC & $\begin{array}{l}\text { This regulation promotes high efficiency } \\
\text { cogeneration of heat and power to } \\
\text { increase energy efficiency and security of } \\
\text { supply. The efficiency of the process is } \\
\text { determined through a specific calculation } \\
\text { method. }\end{array}$ \\
\hline
\end{tabular}

Considering Table II, the amount of regulations directly applying to microgrids for the EU is reduced, which also increases differences between regulations for microgrids in each member state. Nevertheless, the impact of some regulations as 2009/28/EC promoting renewable energies is considerable, since European countries must present plans and strategies feasible in terms of economic and technical aspects to reach 2020 goals.

\section{B. Incentives}

To comply with the goals of European directives in line with microgrids, member states have implemented strategies based on economic incentives. Although the most common support scheme in the EU is based on FITs, other incentives for microgrids with renewable generation [9], [10], [11] are analysed in the following subsections.

\section{1) Feed in tariffs}

Feed in tariffs are incentives based on generation determined by governments for the implementation of renewable energies to accelerate the investment in these technologies [12]. These tariffs include access to grid, longterm energy exchange contracts and trading at market prices for owners. Then, this incentive purchases the investment risk and the price risk related to competition in the market.

In the EU, a well-adapted FIT regime is considered as the most efficient and effective scheme to promote REs [13]. FITs have been the main support system for REs in the EU and, as a consequence, initial investment costs for these technologies have fallen and renewable production has considerably expanded. For this reason, the EC has recently proposed [14] to reduce FITs to the minimum needed so as not to damage the sector and introduce REs into the market with new support schemes.

\section{2) Market Premium}

The market premium provides RE producers extra revenues above energy prices fixed in the market and does not vary with seasonal changes energy costs. In this way, a certain compensation for the investment made is ensured for RE generators. Currently, variable incentives have been implemented, composing a support scheme similar to the FIT (variable premium). However, the difference is that the market premium eliminates price risk but not purchase risk. Nevertheless, as $\mathrm{RE}$ generation technologies have grown considerably and this risk is lower, the EC proposes market premium as a possible alternative for FITs [14]. 


\section{3) Green Certificates}

These programs set annual renewable energy targets and, as a consequence, additional revenues above those from power sales are established for renewable producers to comply with these goals. Green certificates can be traded so that companies comply with RE obligations.

Green Certificates used in Europe are similar to Renewable Energy Credits (REC), Renewable Portfolio Standards (RPC) and tiers and assets implemented in USA.

\section{4) Tenders}

Tenders are emitted to achieve a certain RE generation capacity. Then, an authorised body publishes a tender document to establish contracts with RE producers so that the renewable power goal is met. The selection criteria to choose the most appropriate offer from producers is based on giving preference to proposals willing to receive the minimum tariffs.

Table III shows the support instruments used in the EU in 2010 [15]. As represented, FIT incentives have been the most common system but the situation is expected to change towards market premiums.

Table III. Main support instruments in the EU (2010)

\begin{tabular}{|l|l|}
\hline \multicolumn{1}{|c|}{ Support } & \multicolumn{1}{|c|}{ EU country } \\
\hline Feed-in tariff & $\begin{array}{l}\text { Austria, Bulgaria, Cyprus, France, } \\
\text { Germany, Greece, Hungary, Ireland, } \\
\text { Latvia, Lithuania, Luxemburg, } \\
\text { Portugal, Slovakia, }\end{array}$ \\
\hline Market premium & Denmark, Netherlands \\
\hline Green certificate & Poland, Romania, Sweden \\
\hline $\begin{array}{l}\text { Feed-in tariff }+ \\
\text { Market premium }\end{array}$ & Czech Rep., Estonia, Slovenia, Spain \\
\hline $\begin{array}{l}\text { Feed-in tariff }+ \\
\text { Green certificate }\end{array}$ & Belgium, Italy, UK, \\
\hline
\end{tabular}

\section{Spanish case vs other EU member states}

\section{A. Spanish context for microgrids}

In Spain, the implementation of renewable energy systems is promoted by plans following targets according to European Directives. Recently, the National Renewable Energy Action Plan 2008-2012, in line with the energy goal of Directive 2006/32/EC, has finished. This plan proposed different strategies related to the concept of microgrid (use of renewable generation and energy storage devices, cogeneration) to achieve the EU targets. For this reason, during this period, key incentives were introduced to enhance the penetration of renewable sources. Specifically, remuneration from feed in tariffs (FIT) (used as the incentive method in Spain since 1994, when Royal Decree (RD) 2366/1994 [16] was approved) increased considerably in 2007 with RD 611/2007 [17] for renewable technologies under the Special Regime established initially in Law 54/1997 [18]. Especially, for photovoltaic installations ranging from $100 \mathrm{~kW}$ to 10 MW, FIT remunerations were almost doubled reaching $44.5897 \mathrm{c} € / \mathrm{kWh}$ (upper part of Fig. 2). As a consequence, renewable production from solar $\mathrm{PV}$, increased drastically between 2007 and 2008 because of RD $661 / 2007$ FITs to reach the goals in Directive 2006/32/EC (2758 MW PV installed power were suddenly introduced in 2008 against 557 MW in 2007). This sudden growth supposed the introduction of RD Law 1578/2008 [19] for this technology, reducing the remuneration of these regulated tariffs and classifying installations according to their location. The effect on installed power can be seen in upper part of Fig. 2 (only 167 MW were installed in 2009). In this line, RD $1565 / 2010$ [20], RD Law 14/2010 [21] and RD $1614 / 2010$ [22] were introduced in 2010, limiting the remuneration periods without considering the lifetime of plants, reducing funding and applying correction factors, respectively. As a consequence, production from PV sources keeps almost constant between 2009 and 2012, as upper part of Fig.2 shows.

In 2011, a second Renewable Action Plan [23] was launched specifically to comply with EU 2020 goals in Directive 2009/28/EC. It proposes several ways of complying with these targets related to microgrids, being the most important ones:

- Development of a simplified and homogeneous framework for the installation of renewable generation and energy storage devices with adequate remunerations.

- Change towards the smart grid concept considering self-consumption through net metering

- Promotion of low power renewable generation and real demand management systems enabling the action of final users.

However, these initiatives have not been clearly supported by regulations. Law 15/2012 [24] established the same tax for all electric energy sources, including renewable technologies and RD Law 2/2013 [25] set a "sine die moratorium" for FITs supporting renewable generation sources. In this way, only regulated tariffs are available for renewable energies at the moment. Today, the new Law 24/2013 [26], of the electrical sector, introduced in January 2014 and replacing Law 54/1997, sets the same remuneration for all technologies and will only introduce specific retributions for renewable generation sources in case of the introduction of clear mandates in European directives. Then, the growth in the contribution from renewable sources to the electrical supply seems to be blocked but the compliance with European goals should stimulate the creation of a more appropriate regulatory framework for renewable energies in Spain. 


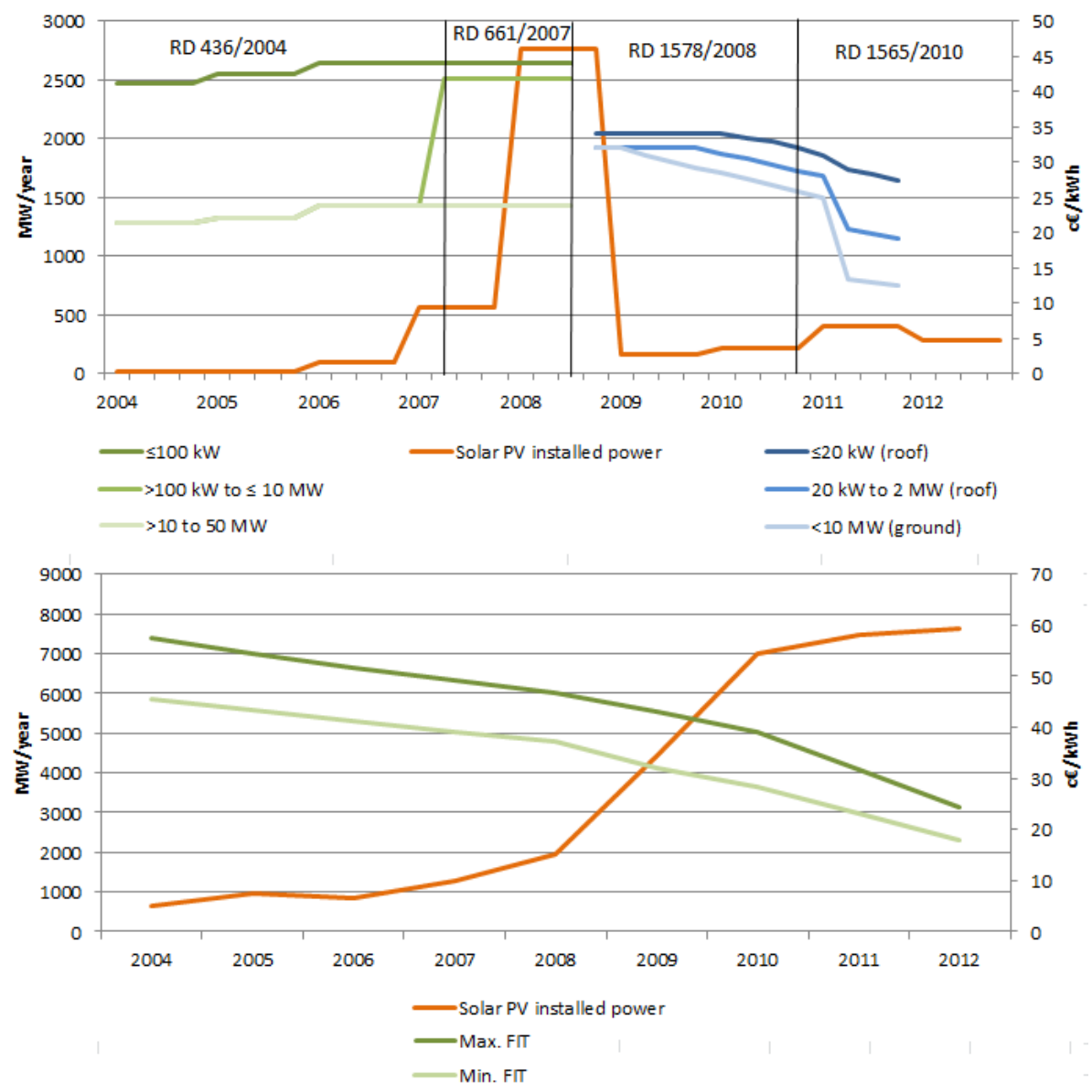

Fig. 2. Evolution of solar PV annual installed power (MW/year) and FITs (c€/kWh) in Spain (top) and Germany (bottom).

\begin{abstract}
About grid connection, the technical and economic aspects are regulated in RD 1955/2000 [27]. In the context of microgrids, RD 1699/2011 [28], which regulates self-consumption through net-metering, limits the microgrid concept since the connection of generation and storage to the same point and islanded operation are not allowed. In this field, law 24/2013 in article 9 has recently classified the different possible net-metering modes but clear incentives have not been introduced since, in case of connection to the distribution grid, the current existing grid access taxes will have to be paid. Besides, islanded operation and the addition of different renewable generation technologies with storage systems connected to the same point have not been considered, in line with RD 1699/2011.
\end{abstract}

As a summary, the following regulatory aspects prevent the implementation of microgrids in Spain:

- Hybridization of RE technologies is not allowed.

- Storage devices cannot be used with RE generation.

- Islanded operation is not allowed.

- Lack of regulations in connection of energy storage installations to the distribution grid.

\section{B. Comparison with other EU member states}

Despite the current Spanish situation, in other member states, European regulations related to microgrids have been successfully implemented. For example, Germany also bases its supporting scheme for renewable sources on FITs providing the necessary security of investment, as established in the Renewable Energy Act (EEG) and its amendment, introduced in 2012. In Germany, the remuneration from FITs has been carefully controlled since photovoltaic energy started to grow considerably with the appropriate regression rates [29], in comparison with the Spanish case, where too high remunerations for investments in the sector were introduced in 2007, an economic bubble was created and RD 1578/2008 did not set the appropriate control mechanisms to solve the problem. This difference can be seen in Fig.2. For the German case (lower part of Fig. 2), FIT remunerations have been continuously decreasing in parallel with the introduction of PV installed power, which grows every year. The possibility of self-consumption is also allowed technically and included in German FITs, which includes the self-consumption segment. In a PV installation, this segment is based on the self-consumption rate, as the energy used from PV energy between the total energy generated by the installation and can reach $30 \%$ [30]. Besides, the use of electric energy storage is funded by KfW bank under the Schwerpunkte Marktanreizprogramm für Batteriespeicher. Up to $30 \%$ of cost can be funded for devices with less than $30 \mathrm{~kW}$. This fact has led to the integration of domestic batteries with PV installations, in such a way that $70 \%$ selfconsumption rates can be achieved [30]. 
On the other hand, Denmark has recently implemented the BEK 804/2010 [31] about self-consumption, which exempts producers in this regime from paying tariffs, duties and VAT for the electricity supplied to the grid, in contrast with the taxes in the Spanish case. Also grid connection possibilities are more suitable for microgrids in other member states. This is the case of the UK, where the installation and connection of renewable electricity generation technologies under $50 \mathrm{~kW}$ and heat supply systems with less than $300 \mathrm{~kW}$ is promoted and granted by the Microgeneration Strategy [32], published in the framework of the Action Plan [33]. About hybridization of different RE technologies, the situation is particularly appropriate in Portugal. Decree Law 363/2007 regulates microgeneration from different RE sources in Portugal and includes a special remuneration (Bonified Tariff) for the first 5 years following the installation, consisting of $650 € / \mathrm{MWh}$ for the first $10 \mathrm{MW}$ and decreasing $5 \%$ for each $10 \mathrm{MW}$ added. The tariff assigns 100\% of remuneration to solar PV installations and $70 \%$ to wind.

\section{Implementation in Europe}

Through the implementation of directive 2009/28/EC, the EU proposed to reach a $20 \%$ share of renewable energy generation. Going beyond this target, the European Renewable Energy Council (EREC) stated that $45 \%$ of energy must come from renewable sources in 2030 [34]. Besides, the influence of some facts has led to an increased promotion of renewable energies, as nuclear disasters in Japan [35] or the economic crisis [36].

This scenario is clearly favourable for the implementation of microgrids. Fig. 3 shows the evolution of investments made in the context of the smart grid in EU as a way of understanding that a clear effort is being made in the direction of microgrids (a microgrid can be seen as a type of smart grid).

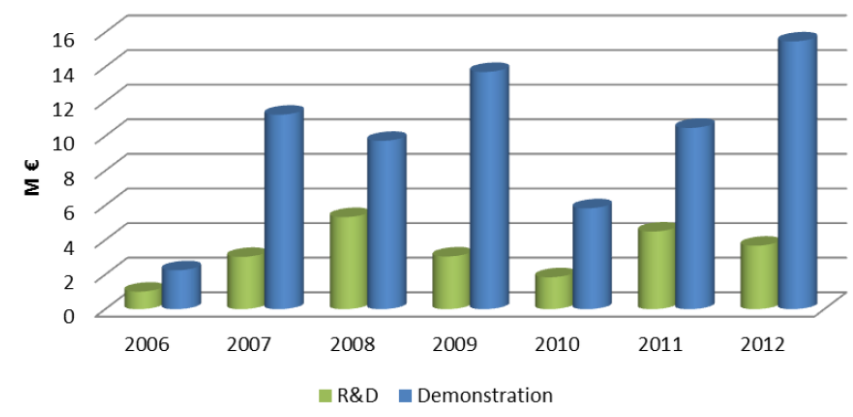

Fig. 3. Evolution of investments for smart grids in the EU [37]

The development of demonstrative microgrid projects in the EU started in the last decade funded by the Framework Programme. In 1999, Microgrids [38] project started and, as a continuation, More Microgrids appears implementing seven demo-sites, being the island of Kythnos (Greece) one of the most representative examples of the implementation of a microgrid. Table IV shows the characteristics of the two arrays composing it [39]. Another case is the SmartCity project developed in Málaga (Spain) [40] at national level. During the first phase of the project, the components in Table $\mathrm{V}$ have been added, composing a system acting as a large microgrid, with MV and LV elements.

Table IV. Kythnos microgrid

\begin{tabular}{|l|c|c|}
\hline Kythnos microgrid & Array 1 & Array 2 \\
\hline Photovoltaic generation $[\mathrm{kW}]$ & 10 & 2 \\
\hline Battery bank [kWh] & 53 & 32 \\
\hline Diesel generator $[\mathrm{kWh}]$ & 5 & - \\
\hline
\end{tabular}

Table V. Málaga SmartCity project

\begin{tabular}{|l|c|c|}
\hline Málaga SmartCity & MV & LV \\
\hline Renewable generation & $13 \mathrm{MW}$ & $33 \mathrm{~kW}$ \\
\hline Energy storage & $106 \mathrm{kWh}$ & $24 \mathrm{kWh}$ \\
\hline Street lighting with: & & \\
- Wind generation & - & $680 \mathrm{~W}$ \\
- PV generation & - & $95 \mathrm{~W}$ \\
\hline
\end{tabular}

The concept of microgrid can also be applied to a district in a city, with loads (e.g. buildings, malls), supplied with renewable distributed generation and storage devices. This is the idea of E+ project (2012-2016), [41] funded by EU $7^{\text {th }}$ Framework Programme in which a new ICT based management tool will be developed to control neighbourhoods. Two demonstrators will be implemented: Málaga (electrical microgrid) and Mons (thermal microgrid).

\section{Conclusions}

This paper has presented a vision of the European regulatory framework involving microgrids. Once considered the advantages of microgrids, its implementation is expected to be definitive in the following years but, at EU level, few directives strictly related to this concept have been introduced. To achieve the goals of these directives, especially Directive 2006/32EC and 2009/28/EC, clear remuneration schemes have appeared for RE producers in the last decade, being mainly based on FITs, although market premiums are being suggested to achieve competition of renewable sources in the energy market and their definitive implementation.

However, the great differences due to the particularities of each member state appear as a considerable barrier, which leads to the fact that the same EU directives can be transposed in multiple ways, leading to very different national regulations. After a regulatory analysis about microgrids policies, the Spanish case appears as a particular situation characterized by retroactive regulations causing legal uncertainty and a considerable impact on renewable installed power to be modified in the following years if EU 2020 goals have to be accomplished. Nevertheless, it can be said that most of member states are introducing regulations in line with the implementation of microgrid concept as a way of complying with EU Directives. Besides, the different investments in microgrid projects in the EU demonstrate the feasibility of this concept. 


\section{References}

[1] European Environmental Agency, "Are energy losses in transformation and distribution declining in Europe?", August 2011.

[2] M. Sanz, J. F. Sanz, M. Calavia, J.M. Perié, "Integración de energías renovables para la mejora de la calidad y la seguridad del suministro eléctrico", Revista CIER, No. 61, pp. 7-17, December 2011.

[3] R.H. Lasseter, "MicroGrids", IEEE Power Engineering Society Winter Meeting 2002, Vol. 1, pp. 305 - 308, January 2002.

[4] N. Hatziargyriu, H. Asano, R. Iravani, C. Marnay, "Microgrids, an overview of ongoing research, development and demonstration projects", IEEE power and energy magazine, July - August 2007.

[5] R.L. Dohn, "The business case for microgrids. White paper: The new face of energy modernization", Siemens AG, 2011.

[6] UNESA, "Emisiones de $\mathrm{CO} 2$ en la Producción de Electricidad en España".

[7] C. Bustos, D. Watts, H. Ren, "MicroGrid Operation and Design Optimization with Synthetic Wind and Solar Resources”, IEEE Latin America Transactions, Vol. 10, No. 2, March 2012.

[8] A.G. Madureira, J.A. Peças Lopes "Ancillary services market framework for voltage control in distribution networks with microgrids", Electric Power System Research. Vol. 86, pp. 1-7, May 2012

[9] A. Izadian, N. Girrens, P. Khayyer, "Renewable Energy Policies: A brief review of the latest U.S. and E.U. policies", Industrial Electronics Magazine, IEEE, Vol. 7, no. 3, pp. 21-34, September 2013.

[10] L. Kitzing, C. Mitchell, and P. E. Morthorst, "Renewable energy policies in Europe: Converging or diverging?" Energy Policy, Vol. 51, pp. 192-201, 2012.

[11] P. Brown, "European Union Wind and Solar Electricity Policies: Overview and Considerations", Congressional Research Service Report for Congress, 7 August 2013.

[12] G. Resch, M. Ragwitz, A. Held, T. Faber, R. Haas, "Feedin Tariffs and quotas for renewable energy in Europe", CESifo DICE report, 4 April 2007.

[13] Commission Staff Working Document, "The Support from renewable energy sources", 23 January 2008.

[14] Communication from the Commission, "Delivering the internal electricity market and making the most of public intervention", 5 November 2013.

[15] M. Ragwitz, M. Rathmann, "Renewable Energy Policies in the EU Member States", Intelligent Energy Europe, 2011.

[16] Real Decreto 2366/1994, de 9 de diciembre, sobre producción de energía eléctrica por instalaciones hidráulicas, de cogeneración y otras abastecidas por recursos o fuentes de energías renovables. Spanish Official Journal (BOE), No. 313, 31 December 1994.

[17] Real Decreto 661/2007, de 25 de mayo, por el que se regula la actividad de producción de energía eléctrica en régimen especial. Spanish Official Journal (BOE), No. 126, 26 May 2007.

[18] Ley 54/1997, de 28 de noviembre, del Sector Eléctrico, Spanish Official Journal (BOE), No. 285, 28 November 1997.

[19] Real Decreto 1578/2008, de 26 de septiembre, de retribución de la actividad de producción de energía eléctrica mediante tecnología solar fotovoltaica para instalaciones posteriores a la fecha límite de mantenimiento de la retribución del Real Decreto 661/2007, de 25 de mayo, para dicha tecnología. Spanish Official Journal (BOE), No. 126, 26 May 2007. [20] Real Decreto 1565/2010, de 19 de noviembre, por el que se regulan y modifican determinados aspectos relativos a la actividad de producción de energía eléctrica en régimen especial, Spanish Official Journal (BOE), No. 283, 23 November 2010.
[21] Real Decreto-ley 14/2010, de 23 de diciembre, por el que se establecen medidas urgentes para la corrección del déficit tarifario del sector eléctrico, Spanish Official Journal (BOE), No. 312, 24 December 2010.

[22] Real Decreto 1614/2010, de 7 de diciembre, por el que se regulan y modifican determinados aspectos relativos a la actividad de producción de energía eléctrica a partir de tecnologías solar termoeléctrica y eólica, Spanish Official Journal (BOE), No. 298, 8 December 2010.

[23] Plan de Acción Nacional de Energías Renovables de España (PANER) 2011-2020, Ministerio de Industria, Turismo y Comercio, pp. 49-148, 30 June 2010.

[24] Ley 15/2012, de 27 de diciembre, de medidas fiscales para la sostenibilidad energética. Spanish Official Journal (BOE), No. 312, 28 December 2012.

[25] Real Decreto-ley $2 / 2013$, de 1 de febrero, de medidas urgentes en el sistema eléctrico y en el sector financiero, Spanish Official Journal (BOE), No. 29, 2 February 2013.

[26] Ley 24/2013, de 26 de diciembre, del Sector Eléctrico, Spanish Official Journal (BOE), No. 310, 27 December 2013.

[27] Real Decreto 1955/2000, de 1 de diciembre, por el que se regulan las actividades de transporte, distribución, comercialización, suministro y procedimientos de autorización de instalaciones de energía eléctrica. Spanish Official Journal (BOE), No. 310, 27 December 2000.

[28] Real Decreto 1699/2011, de 18 de noviembre, por el que se regula la conexión a red de instalaciones de producción de energía eléctrica de pequeña potencia.Spanish Official Journal (BOE). No. 295, 8 December 2011.

[29] J. Hoz, H. Martin, J. Ballart, F. Córcoles, M. Graells, "Evaluating the new control structure for the promotion of grid connected photovoltaic systems in Spain: Performance analysis of the period 2008-2010", Renewable and Sustainable Energy Reviews, Volume 19, March 2013

[30] T. Drizard, "German Energy Policy: Reconciling Energy Storage and Feed-in Tariffs with Self-consumption Tariffs", Clean Horizon Consulting, 3 April 2012.

[31] BEK 804/2010, Regulation on Net-metering for the Producers of Electricity for Own Needs, 21 March 2012.

[32] Microgeneration Strategy. Department of Energy and Climate Change, 2011.

[33] Action Plan. Microgeneration Government-Industry Contact Group, June 2011.

[34] J. Muth, E. Smith, " $45 \%$ by 2030: Towards a truly sustainable energy system in the EU", European Renewable Energy Council (EREC), 2011.

[35] J. Hsu, "Japan Plants Renewable Energy Village in Fukushima's Contaminated Farmland", IEEE Spectrum, 6 January 2014.

[36] European Commission, "Skills of tomorrow's green economy", Intelligent Energy Europe Magazine, December 2012.

[37] V. Giordano, A. Meletiou, C.F. Covrig, A. Mengolini, M. Ardelean, G. Fulli, M. Sánchez, C. Filiou, "Smart Grid projects in Europe: Lessons learned and current developments", Joint Research Centre, 2013.

[38] Microgrids project. http://www.microgrids.eu [accessed 16.01.14].

[39] S. J. Chatzivasiliadis, N. D. Hatziargyriou, "Development of an Agent Based Intelligent Control System for Microgrids", Power and Energy Society General Meeting - Conversion and Delivery of Electrical Energy in the 21st Century, IEEE, Vol. 1, No. 6, pp. 20-24, July 2008.

[40] A. Arcos, "Los proyectos SmartCity de Endesa", Endesa Distribución Eléctrica, 6 June 2012.

[41] E+ Project. http://www.eplusproject.eu/ [accesed 16.01.14]. 